\title{
Healthy Eating Concern (Orthorexia Nervosa) and Related Factors in Women
}

\author{
Merve Şeyda KARAÇILL ERMUMCU and Nilüfer ACAR TEK* \\ Department of Nutrition and Dietetic, Turkey
}

*Corresponding author: Nilüfer ACAR TEK, Faculty of Health Science, Department of Nutrition and Dietetic, Ankara, Turkey

Submission: 眥 April 13, 2018; Published: 眥 May 16, 2018

\begin{abstract}
Objective: This study was conducted in order to evaluate healthy eating obsession-orthorexia nervosa and related factors in women.

Method: The study was carried out 132 volunteer women aged between 20-54 years. Demographic characteristics, health information were taken and orthorexia nervosa-15 (ORT0-15) was applied by researcher with face to face method. Antropometric measurements were taken according to the rules. It was determinated that ORTO-15 score $\leq 40$ is orthorexic and $>40$ is normal. Data was evaluated using chi-square, analysis of t-test and correlation analysis methods with SPSS16.0 program.

Result: It was found that $75.8 \%$ of women has less than 40 points from 0RTO-15 test. There is a negative correlation between 0RTO-15 score with age $(r=-0.183)$, body weight $(r=-0.206)$ and BMI $(r=-0.199)(p<0.05)$. It was seen that obsessional concerns such as choosing healthy food and this dietary pattern to be associated with physical appearance are common in orthorexic individuals.

Conclusion: It was found that orthorexia tendency of women has higher. It has been observed that orthorexic tendencies are increased in individuals with high body weight and BMI values. Determination of obsessional concerns of orthorexic individuals will be useful in the classification of the disease and development of diagnostic criteria.
\end{abstract}

Keywords: Orthorexia nervosa; Nutrition; Women

Abbreviations: ORT0-15: Orthorexia Nervosa-15; BMI: Body Mass Index

\section{Introduction}

As the importance of nutrition is emphasized in the prevention and treatment of diseases and improvement of health, awareness of healthy nutrition is increasing in society. In orthorexia nervosa, individuals adopt a nutritional style for purposes such as protecting and improvement of health, treating disease or losing weight. However, this nutrition style affects the life of individuals and also it may trigger nutritional deficiencies that threaten health and even causing eating behaviour disorders [1-3].

Orthorexic individuals usually prefer healthy and pure nutrients and they care the quality of food rather than amount [4,5]. In addition, they also show anxious behaviors about food preparation and cooking techniques and sterilization of cooker. They don't consume food that is unfamiliar and unreliable [2]. Due to their obsession they often consume pure and additive-free foods, they tend to consume fruit and raw foods [6]. Orthorexic individuals who are struggling with healthy nutrition are often faced with severe weight loss and malnutrition as in other eating disorders [1,4-6]. But these individuals lose weight because of triying consume healthy foods and make their diet perfect mentally and not to look better like anorexia nervosa and bulimia nervosa [7]. However, negative feelings such as regret and wanting to be extremely weak are not observed [3].

Along with the increasing interest in orthorexia nervosa, the number of studies for determining the prevalence orthorexia nervosahas also been steadily increasing. The prevalence of orthorexic tendency varies between $41 \%$ and $60 \%$ in studies conducted in Europe $[1,4,8,9]$. Studies conducted in the United States indicated that the prevalence of orthorexia varies between $69 \%$ and $82.8 \%[10,11]$. These studies showed that orthorexia tendencies are common. This study was planned and conducted to determine the tendency of orthorexia nervosa in women.

\section{Material and Methods}

This study was conducted with 132 volunteer women aged between 20-54 years in Ankara. Health related anxiety, appearance focused problems, being more relevant in nutrition knowledge than men may be major factors for the selection of women as a working group. The demographic characteristics of the individuals were recorded in the questionnaire by face-to-face method 
and Orthorexia Nervosa-15 (ORTO-15) scale was applied and anthropometric measurements were taken by the researchers.

\section{Anthropometric Measurements}

Anthropometric measurements, including weight, height, waist circumference were measured by well-trained investigators, using standard measurement protocols and body mass index (BMI) was calculated [12-15].

\section{Orthorexia Nervosa (ORTO-15)}

The ORTO-15 questionnaire is a tool consisting of 15 items describing the intensificationof the orthorexic behaviour. A 15-question likert type scale developed by Donini et al. [16] based on the questionnaire prepared by the first researchers Bratman \& Knight [15]. The question of scale investigates the obsessive behavior of individuals in selecting, purchasing, preparing and

\section{Result}

Table 1: Evaluation of general characteristics and anthropometric measurements of normal and orthorectic individuals.

\begin{tabular}{|c|c|c|c|}
\hline & Orthorexic (n:100) $\overline{\mathbf{x} \pm \mathbf{S}}$ & Normal $(\mathbf{n}: \mathbf{3 2}) \overline{\mathbf{x} \pm \mathbf{S}}$ & $\mathbf{p}$ \\
\hline Age (year) & $34.7 \pm 8.77$ & $30.9 \pm 8.03$ & $0.034^{*}$ \\
\hline Education duration (year) & $16.2 \pm 2.70$ & $17.0 \pm 2.88$ & 0.218 \\
\hline Body weight $(\mathrm{kg})$ & $63.5 \pm 9.77$ & $59.7 \pm 7.45$ & $0.022^{*}$ \\
\hline Height $(\mathrm{cm})$ & $163.0 \pm 5.66$ & $161.6 \pm 5.09$ & 0.189 \\
\hline Waist circumference $(\mathrm{cm})$ & $80.7 \pm 10.51$ & $78.7 \pm 8.98$ & 0.298 \\
\hline BMI $\left(\mathrm{kg} / \mathrm{m}^{2}\right)$ & $23.9 \pm 3.68$ & $22.8 \pm 2.81$ & 0.09 \\
\hline ORTO-15 & $36.1 \pm 2.85$ & $42.7 \pm 1.84$ & $0.000^{* *}$ \\
\hline
\end{tabular}

t test; ${ }^{*} \mathrm{p}<0.05,{ }^{* *} \mathrm{p}<0.01$, ORT0-15:Orthorexia nervosa-15,BMI: Body mass index.

ORTO-15 $\leq 40$ : orthorexic, ORTO-15 >40: normal.

It was determined that $75.8 \%$ of the participants showed orthorectic tendency. Mean age, body weight, waist circumference, and BMI of individuals with orthorexic tendency were significantly higher than normal indivuduals and ORTO-15 scores were lower $(\mathrm{p}<0.05)$. The duration of education duration was lower in orthorexic and no statistically significant difference was found between the groups ( $\mathrm{p}>0.05)$ (Table 1$)$.

Table 2: Evaluation of anthropometric measurements with ORTO-15 scores of individuals.

\begin{tabular}{|c|c|c|}
\hline & ORTO-15 & p \\
\hline & $\mathbf{r}$ & 0.036 \\
\hline Age (year) & $-0.183^{*}$ & 0.08 \\
\hline Education duration (year) & 0.153 & 0.018 \\
\hline Body weight (kg) & $-0.206^{*}$ & 0.126 \\
\hline Waist circumference $(\mathrm{cm})$ & -0.134 & 0.041 \\
\hline Desired body weight $(\mathrm{kg})$ & $-0.179^{*}$ & 0.022 \\
\hline BMI $\left(\mathrm{kg} / \mathrm{m}^{2}\right)$ & $-0.199^{*}$ & \\
\hline
\end{tabular}

Pearson correlation, * ${ }^{*}<0.05$, BMI: Body mass index.

When the relationship between individual's ORTO-15 scores and anthropometric measurements was evaluated, age, body weight, desired body weight and BMI values were found to be negatively associated with ORTO-15 score $(\mathrm{p}<0.05)$ (Table 2). consuming food that they perceive as healthy. At least 15 points and a maximum of 60 points can be taken from the scale. ORTO- 15 scale score $\leq 40$ orthorexia risk, $>40$ points were considered normal [16].

Statistical analysis was performed with version 16 SPSS. Mean and standard deviation values of quantitative data obtained from individuals were given in tables according to orthorexia tendency. Significance was assessed using t-test or chi-square test for parametric data and Mann-Whitney U test for nonparametric data. Correlation between 0RT0-15 scores and certain anthropometric measurements and were calculated using Sperman/Pearson test. The difference between the groups in categorical variables (number and percentage) was evaluated by square test. Statistical significance was assessed at $\mathrm{p}<0.05$ level 
food may improve your appearance?". 33.0\% of individuals with orthorectic tendency answered always and 34\% of them answered often in the question:" Do you think that the conviction to eat only healthy food increases self-esteem?". 33.0\% of individuals with orthorectic tendency answered always in the question:"Do you feel guilty when you are fed unhealthy?" ( $\mathrm{p}<0.05)$ (Data not shown).

\section{Discussion}

Orthorexia nervosa is a eating behavior disorder characterized by pathological obsessions to natural and healthy nutrition [17]. This situaition is defined as anxiety about healthy eating and it causes emergence of orthorexic tendencies in individuals and pathological consequences such as eating behavior disorders progressively. Although orthorexia nervosa has not yet been categorized as a disease, it has attracted the attention of researchers working in this field because of the relationship with eating behavior disorders. But the investigations are mainly focused on non-clinical prevalence studies [2,18-25].

In our country, the prevalence of orthorexia changes between $41 \%$ and $46 \%$ in different age groups in different studies evaluating the tendency of orthorexia nervosa $[4,9,17]$. In this study, in which the female individuals were evaluated, it was seen that the prevalence of orthorexia $(75.8 \%)$ was higher than the previous studies.

It was reported that orthorexia nervosa correlates with gender $[1,7,22,23]$, education level [5,8], body weight [11] and BMI $[5,8,18,23-25]$ in different studies. There was conflicting conclusion about relationship between tendency of orthorexia nervosa and gender. Studies have shown that prevalence of orthorexia nervosa is higher in men $[5,18]$ but recent studies has shown that the tendency of orthorexia especially is more in women in recent years $[1,7,22,23]$ and it was shown that 2.5 times more than men [23]. In this study, it is suggested that research population consists of women and this may effective to be higher of the prevalence of orthorexia (75.8\%).

Although Arusoglu et al. [1] stated that age did not have effect on the orthorexia tendency but other studies $[5,9,18]$ found a negative relationship between ORTO-15 score and age and reported that advancing age may be effective in increasing orthorexia tendencies. Similar to other studies, correlation was found between low ORTO15 scores and high age $(\mathrm{p}<0.05)$ in this study,

According to the researches, the relationship between the orthorexia tendency of individuals and the duration of education is contradictory. Donini et al. [5] showed that the orthorexic tendency was high in low levels of education with individuals. However, in some studies has been reported that educational status is not effective alone on orthorectic tendency $[16,26]$. In this study, although education duration of orthorectic individuals was lower than normal individuals, the difference was not statistically significant between groups ( $\mathrm{p}>0.05)$.
It was stated that orthorexic individuals limit their choice of nutrients for healthy nutrition and this situationcause weight loss [3]. In this study, mean body weights of individuals with orthorexic tendency were found to be higher than normal individuals $(p<0.05)$ (Table 1). In addition, body weight they wanted to be was questioned and found to be negatively correlated with ORTO-15 scores (Table 2 ). This result suggests that being overweight and obese may be a trigger for a healthy nutritional obsession in increasing orthorexic tendencies. The weakness that emerges as orthorexic obsessions progress will be a consequence of this advancing process.

In some studies, it has been suggested that body mass index may be an indicator predicting orthorexic behavior [18,24,25]. Especially it has been reported that high BMI values are associated with low ORT0-15 scores $[4,18,26]$. However, it was showed that no relationship between 0RT0-15 score and BMI values in some studies $[1,23,27]$. There was a significant negative correlation between ORTO-15 score and also BMI values and those with low ORTO-15 scores had higher BMI values (r:-0.199; p:0.022) in this study. For this reason, it is possible to say that being normal body weight and maintaining it can protect against orthorexic tendencies or as increased body weight increases tendency of orthorexia.

When general nutritional behavior of orthorexic tendency is examined, they are obsessed with the quality of the food than quantity. They have label reading habits when purchasing any food and also they prefer pure and additive-free food and not the presence of additives and carcinogens in the food [5]. In this study, more than half of the individuals with orthorexic tendency (52.9\%) stated that they always "like to spend more money to buy healthier foods". Although it was reported that they have no fears about body perceptions and obesity. $69 \%$ of individuals with orthorexic tendency always think that consuming healthy food may improve their appearance. Healthy nutritional obsession can have negative effects on the body sensation in the future and desiring to make the physical appearance better prone to health problems such as energy and nutrients deficiencies and malnutrition.

\section{Conclusion}

It was determined that orthorexia nevrosa was remarkably high in this cross-sectional study. It has been observed that orthorexic tendencies are increased in individuals with high body weight and BMI values. Orthorexic individuals significantly differ from normal individuals and they are very sensitive some topics; they are more anxious about foods, they feel guilty when they consume the foods that they think are unhealthy, they are ready to pay more money to buy healthy food and also they believe that healthy eating may affect their physical appearance. Determination of obsessional concerns of orthorexic individuals will be useful in the classification of the disease and development of diagnostic criteria.

\section{References}

1. Arusoğlu G, Kabakçı E, Köksal G, Merdol TK (2008) Ortoreksiya Nervoza ve Orto-11' in Türkçeye Uyarlama Çalıșması. Türk Psikiyatri Derg 19(3): 283-291. 
2. Catalina Zamora MB, Bote Bonaechea B, Garcia Sánchez F, Rios Rial B (2005) Orthorexia nervosa: A new eating behavior disorder? Actas Esp Psiquiatr 33(1): 66-68.

3. Gezer C, Kabaran S (2013) Beslenme ve diyetetik bölümü kız öğrencileri arasında görülen ortoreksiya nervosa riski. SDÜ Sağlık Bilimleri Dergisi 4(1): 14-22.

4. Asil E, Sürücüoğlu MS (2015) Orthorexia Nervosa in Turkish Dietitians. Ecol Food Nutr 54(4): 303-313.

5. Donini LM, Marsili D, Graziani MP, Imbriale M, Cannella C (2004) Orthorexia nervosa: A preliminary study with a proposal for diagnosis and an attempt to measure the dimension of the phenomenon. Eat Weight Disord 9(2): 151-157.

6. Alvarenga MS, Martins MC, Sato KS, Vargas SV, Philippi ST, et al. (2012) Orthorexia nervosa behavior in a sample of Brazilian dietitians assessed by the Portuguese version of ORTO-15. Eat Weight Disord 17(1): e29-e35.

7. Koven NS, Abry AW (2015) The clinical basis of orthorexia nervosa emerging perspectives. Neuropsychiatr Dis Treat 18(11): 385-394.

8. Aksoydan E, Camcı N (2009) Prevalence of orthorexia nervosa among Turkish performance artists. Eat Weight Disord 14(1): 33-37.

9. Bagcı Bosi AT, Çamur D, Güler Ç (2007) Prevalence of orthorexia nervosa in resident medical doctors in the faculty of medicine (Ankara, Turkey). Appetite 49(3): 661-666.

10. Jesko A (2015) Orthorexia Nervosa: Psychological disorder or Social Trend? Texas State University. Texas, USA.

11. McInerney, Ernst EM (2011) Orthorexia nervosa: Real construct or newest social trend? Pro Quest Information \& Learning, Kansas City, Missouri, USA.

12. Ben Noun L, Sohar E, Laor A (2001) Neck circumference as a simple screening measure for identifying overweight and obesity patients. Obes Res 9(8): 470-474.

13. Lohman TG, Roche AF, Martoel R (1998) Antropometric Standarsization Reference Manual, Kinetic Books, Champaign, İllinois, USA.

14. WHO (2014) Body mass index-BMI.

15. Bratman S, Knight D (2000) Health Food Junkies: Overcoming the Obsession with Healthful Eating, Broadway Books, New York, USA, pp. $1-242$.
16. Donini LM, Marsili D, Graziani MP, Imbriale M, Cannella C (2005) Orthorexia nervosa: Validation of a diagnosis questionnaire. Eating Weight Disord 10(2): e28-e32.

17. Brytek Matera A (2012) Orthorexia nervosa-an eating disorder, obsessive-compulsive disorder or disturbed eating habit? Arch Psychiatry Psychother 14(1): 55-60.

18. Fidan T, Ertekin V, Isikay S, Kırpınar I (2010) Prevalence of orthorexia among medical students in Erzurum, Turkey. Compr Psychiatry 51(1): $49-54$

19. Kinzl JF, Hauer K, Traweger CH, Kiefer I (2006) Orthorexia nervosa in dieticians. Psychother Psychosom 75(6): 395-396.

20. Korinth A, Schiess S, Westenhoefer J (2010) Eating behaviour and eating disorders in students of nutrition sciences. Public Health Nutr 13(1): 32-37.

21. Dunn TM, Gibbs J, Whitney N, Starosta A (2016) Prevalence of orthorexia nervosa is less than $1 \%$ : data from a US sample. Eat Weight Disord 22(1): 185-192

22. Koven NS, Abry AW (2015) The clinical basis of orthorexia nervosa: emerging perspectives. Neuropsychiatr Dis Treat 18(11): 385-394.

23. Sanlıer N, Yassibas E, Bilici S, Sahin G, Celik B (2016) Does the rise in eating disorders lead to increasing risk of orthorexia nervosa? Correlations with gender, education, and body mass index. Ecol Food Nutr 55(3): 266-278

24. Stochel M, Joanna Hyrnik JH, Ireneusz Jelonek IJ, Jan Zejda JZ, Malgorzata Janas Kozik MJK (2013) Orthorexia among Polish urban youth. Eur Neuropsychopharmacol 23(2): 527-528.

25. Varga M, Thege BK, Dukay Szabó S, Túry F, Furth EF (2014) When eating healthy is not healthy: orthorexia nervosa and its measurement with the ORTO-15 in Hungary. BMC Psychiatry 28(14): 59.

26. Varga M, Dukay Szabó S, Túry F, van Furth EF (2013) Evidence and gaps in the literature on orthorexia nervosa. Eat Weight Disord 18(2): 103111.

27. Segura Garcia C, Ramacciotti C, Rania M, Aloi M, Caroleo M, et al. (2014) The prevalence of orthorexia nervosa among eating disorder patients after treatment. Eat Weight Disord 20(2): 161-166.
Creative Commons Attribution 4.0 International License

For possible submissions Click Here

\section{Submit Article}

\section{COJ Nursing \& Healthcare}

\section{Benefits of Publishing with us}

- High-level peer review and editorial services

- Freely accessible online immediately upon publication

- Authors retain the copyright to their work

- Licensing it under a Creative Commons license

- Visibility through different online platforms 